\title{
Kaposi's sarcoma associated with hairy cell leukaemia
}

\author{
K. M. DE COCK* \\ M.R.C.P., D.T.M. \& H. \\ S. B. LUCAS* \\ M.R.C.P., M.R.C.Path. \\ N. R. GICHUYIA $\dagger$ \\ M.B., Ch.B.
}

E. G. KASILI $\dagger$

M.D. (Nairobi), M.R.C.Path.

K. RADIA $\dagger$

M.B., M.R.C.Path.

B. M. WANKYA $\dagger$

M.B., M.Med.(Makerere)

*Unit of Geographical Pathology, St Thomas's Hospital Medical School, London SE1 7EH and

$\dagger$ Departments of Medicine and Human Pathology, University of Nairobi, Kenyatta National Hospital, Nairob

\begin{abstract}
Summary
The case is described of a patient with hairy cell leukaemia who later developed Kaposi's sarcoma. This association has not been reported before and the coexistence of hairy cell leukaemia with another tumour is very rare. The implications of this unusual association are briefly discussed.
\end{abstract}

KEY WORDS: Kaposi's sarcoma, hairy cell leukaemia.

\section{Introduction}

Hairy cell leukaemia is a rare condition and the patient reported here is only the third such case out of 527 patients with all types of leukaemia seen at our hospital over the last 4 years.

A second malignancy in a patient with hairy cell leukaemia has been documented in detail only once before (Adler, Shetty and Golomb, 1979). The association of Kaposi's sarcoma, a common tumour in parts of sub-Saharan Africa, with hairy cell leukaemia is of interest, not only because of the rarity of such an event, but also in the light of recent discussion about a possible infective aetiology for Kaposi's sarcoma.

\section{Case report}

A 58-year-old Kikuyu male presented with a 2 month history of abdominal distension and weight loss. His home was in Nyeri District in the Central Province of Kenya, an area where neither malaria nor Schistosoma mansoni are transmitted to any significant degree. Examination revealed a thin man with a palpable liver $10 \mathrm{~cm}$ below the costal margin and spler. omegaly to the umbilicus.

Investigations were as follows: haemoglobin 12.1 $\mathrm{g} / \mathrm{dl}$, white cell count $10 \times 10^{9} / 1$, platelets $115 \times 10^{9} / \mathrm{l}^{\infty}$ The white cell differential showed $33 \%$ neutrophils? 4\% monocytes, $49 \%$ lymphocytes, $8 \%$ undefine $\vec{s}$ mononuclear cells and $6 \%$ characteristic hairy cellso Bone marrow aspiration yielded a hypercellula marrow with no obvious abnormal white cegls $s_{\infty 0}^{\circ}$ Staining for tartrate resistant acid phosphatase not possible. Hairy cell leukaemia was diagnosed splenectomy was carried out. The spleen weige $1050 \mathrm{~g}$ and showed malignant lymphoid cells infil trating the sinusoids.

Recovery was uneventful, but 4 months after hid initial presentation, he returned with painful nodule over the feet and lower legs which had been presen? for 8 weeks. The white cell count was now $13.9 \times 10^{9} / 1$ with $37 \%$ neutrophils, $18 \%$ monocytes $26 \%$ lymphocytes, $1 \%$ eosinophils, $13 \%$ undefine mononuclear cells and 5\% hairy cells. Repeat bone marrow examination showed hairy cell infiltratio and biopsy of one of the nodules confirmed Kaposi's. sarcoma. Treatment has been started with radiother apy to the legs and intravenous vincristine and cyclophosphamide at weekly intervals with some resolution of the nodules.

\section{Discussion}

Hairy cell leukaemia is probably a chronic malig nancy of the B lymphocyte series. Infection is arw important complication and may reflect reduce neutrophils and monocytes and altered monocyte function (Golomb, Catovsky and Golde, 1978) There has been only one detailed report of a patient with hairy cell leukaemia developing a second malignancy, an histiocytic lymphoma (Adler, Shetty and Golomb, 1979). 
Kaposi's sarcoma is the tenth commonest malignancy seen in Kenya, making up $2.5 \%$ of all tumours. The association of Kaposi's sarcoma with other primary cancers is well recognised, particularly with lympho-reticular malignancies (Safai et al., 1980). In our patient, hairy cell leukaemia appeared to be the first disease, Kaposi's sarcoma only developing several months after haematological diagnosis.

The aetiology of Kaposi's sarcoma remains uncertain, but an infective agent has been proposed. Timespace clustering has been observed in the West Nile District of Uganda, analagous to observations on Burkitt's lymphoma, and there is evidence linking cytomegalovirus with the tumour (Giraldo, Beth and Kyalwazi, 1981; Greenwood and Whittle, 1981). A large number of cases of Kaposi's sarcoma have recently been reported in the United States in young homosexual men (Hymes et al., 1981; Durack, 1981). Many of these patients had cytomegalovirus infection, as well as hepatitis B, and the possibility of venereal transmission of a causative infective agent has been raised. Altered immunity is almost certainly part of the reason why this tumour was able to develop in this special group of patients (Durack, 1981; Editorial, 1981).

While the association of 2 neoplastic conditions in our patient may have been fortuitous, it is possible that Kaposi's sarcoma, whatever its aetiology, devel- oped in this man whose immune system had been rendered defective by hairy cell leukaemia. An alternative explanation is that both malignancies were induced by the same oncogenic agent, either directly or as a result of impaired tumour surveillance from immunosuppression.

\section{References}

AdLeR, S.S., ShetTy, J. \& Golomb, H.M. (1979) Coexistence of leukaemic reticuloendotheliosis and histiocytic lymphoma. Cancer, 43, 1872.

DURACK, D.T. (1981) Opportunistic infections and Kaposi's sarcoma in homosexual men. New England Journal of Medicine, 305, 1465.

EDITORIAL (1981) Immunocompromised homosexuals. Lancet, ii, 1325.

GiRAldo, G., Beth, E. \& KYAlwazi, S.K. (1981) Etiological implications on Kaposi's sarcoma. Antibiotics and Chemotherapy, $29,12$.

GolomB, H.M., Catovsky, D. \& GolDE, D.W. (1978) Hairy cell leukemia. Annals of Internal Medicine, 89, 677.

GREENWOOD, B.M. \& WHITTLE, H.C. (1981) Immunology of Medicine in the tropics, p. 229. Edward Arnold, London.

hymes, K.B., Cheung, T., Greene, J.B.M., Prose, N.J., Marcus, A., Ballard, H., William, D.C. \& Laudenstein, L. (1981) Kaposi's sarcoma in homosexual men-a report of eight cases. Lancet, ii, 598.

Safal, B., Mike, V., Giraldo, G., Beth, E. \& Good, R.A. (1980) Association of Kaposi's sarcoma with second primary malignancies. Cancer, 45, 1472.

(Accepted 16 July 1982) 